\title{
Photocatalytic properties of silica gel beads coated by $\mathrm{Ag}_{2} \mathrm{O}-\mathrm{V}_{\mathbf{2}} \mathrm{O}_{5}$
}

\author{
KıYoshı KURIBAYASHI - Teikyo University of Science \& Technology - kuribaya@ntu.ac.jp \\ DAISUKE OHMIYA - Teikyo University of Science \& Technology \\ Received: 10.06.2009. - Érkezett: 2009.06.10. http://dx.doi.org/10.14382/epitoanyag-jsbcm.2010.3
}

Kiyoshi KURIBAYASHI was born in 1949 in Japan. After he received his doctor degree in 1979 in material science from Tokyo Institute of Technology, he went to McMaster University to work with Prof. P. Nichlson in 1980. He then joined to Matsushita Electric Co., LTD. in 1982. He has worked at Teikyo University of Science \& Technology since

Daisuke OHMIYA

Silica gel beads were coated by $\mathrm{AgVO}_{3}, \mathrm{Ag}_{4} \mathrm{~V}_{2} \mathrm{O}_{7}$ and $\mathrm{Ag}_{3} \mathrm{VO}_{4}$ to study their photocatalytic performance. The model reaction was the decomposition of methylene blue and acetaldehyde, respectively in fluorescent and ultraviolet radiation and in darkness, as well. The photocatalytic films formed on the surface of silica gel beads had a thickness of about $400 \mathrm{~nm}$. No film exfoliation was observed during the decomposition experiments. The photocatalytic activity of silica gel beads coated by given compounds was much higher as compared to powder samples. An especially remarkable decomposition of methylene blue was detected on $\mathrm{Ag}_{3} \mathrm{VO}_{4}$ coated silica gel beads: concentration of methylene blue decreased from $10 \mathrm{mg} / \mathrm{dm}^{3}$ to less than $0.01 \mathrm{mg} / \mathrm{dm}^{3}$ for $16 \mathrm{~h}$ under fluorescent light irradiation. It was also observed that addition of Pt co-catalyst to the coating film improved the photocatalytic performance.

Keywords: photocatalyst, $\mathrm{Ag}_{2} \mathrm{O}_{-} \mathrm{V}_{2} \mathrm{O}_{5}$ compounds, methylene blue decomposition, acetaldehyde decomposition

\section{Introduction}

From the viewpoint of the utilization of solar energy and indoor illumination, visible light responsive photocatalyst has been desired for green technology which mainly includes oxidative decomposition of the volatile organic compounds and purification of water. A number of studies have been carried out for visible light responsive photocatalyst. Wolframite type oxide compound $[1,2]$ such as $\mathrm{InNbO}_{4}$ and $\operatorname{InMTaO}_{4}(\mathrm{M}=\mathrm{Cu}$, $\mathrm{Ni}, \mathrm{Co}, \mathrm{Fe}, \mathrm{Mn}$ ) and oxinitride [3] such as $\mathrm{TaON}$ were reported. Vanadate compounds have been also studied as visible light photocatalyst $[4,5]$. We reported that powder of indium vanadate synthesized via coprecipitation and pyrolysis method decomposed methylene blue under fluorescent light irradiation and absorbed a light shorter wavelength than $580 \mathrm{~nm}$ [6]. The compounds in the system $\mathrm{Ag}_{2} \mathrm{O}-\mathrm{V}_{2} \mathrm{O}_{5}$ synthesized via solid state reaction were previously reported that absorption edge of the compounds were measured to be approximately $480 \mathrm{~nm}$ and the compounds decomposed methylene blue under fluorescent light irradiation [7]. Powder type photocatalyst however is not suitable for the application of photocatalyst to green technology because of difficulty of collection of powder sample.
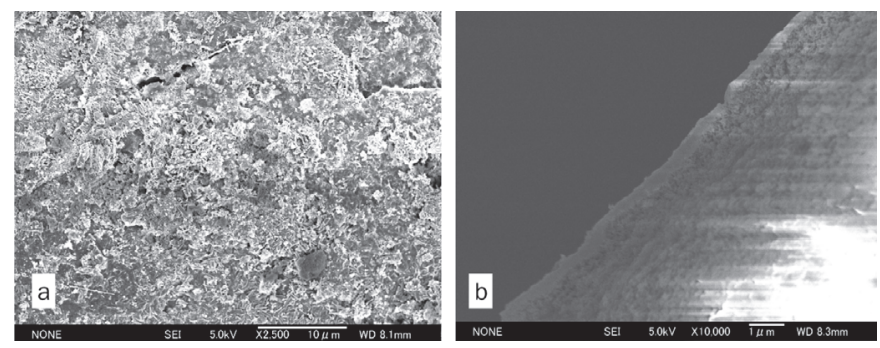

Fig. 1. SEM photographs of $\mathrm{AgVO}_{3}$ coated silica gels produced at $400{ }^{\circ} \mathrm{C}$ (a) surface view and $(b)$ cross sectional view

1. ábra $400{ }^{\circ} \mathrm{C}$ hömérsékleten szintetizált, $\mathrm{AgVO}_{3}$ bevonatú szilikagél gyöngyök pásztázó elektronmikroszkópos felvételei. (a) külső felület, (b) keresztmetszet

In the present study, precursor solution of $\mathrm{Ag}_{2} \mathrm{O}-\mathrm{V}_{2} \mathrm{O}_{5}$ compounds, such as $\mathrm{AgVO}_{3}, \mathrm{Ag}_{4} \mathrm{~V}_{2} \mathrm{O}_{7}$ and $\mathrm{Ag}_{3} \mathrm{VO}_{4}$, was prepared and coated to silica gel beads. Photocatalytic properties of silica gel beads coated by $\mathrm{Ag}_{2} \mathrm{O}-\mathrm{V}_{2} \mathrm{O}_{5}$ were evaluated from measurements of decomposition of methylene blue and acetaldehyde under irradiation of fluorescent light, black light and in dark. ICP atomic emission spectroscopy measurement was carried out to elucidate the photodissolution of components from the compounds into solution during the methylene blue decomposition experiment. Effect of Pt co-catalyst loading to photocatalyst coated silica gel beads was also examined in the present study.

\section{Experimental}

\subsection{Preparation of silica gel beads coated by $\mathrm{Ag}_{2} \mathrm{O}-\mathrm{V}_{2} \mathrm{O}_{5}$}

Appropriate amount of silver nitrate (Kanto Chemical: 99.8\%) and ammonium vanadate (Kanto Chemical: 99.0\%) were dissolved together in $1 \mathrm{~N}$ ammonia solution. The precursor solutions of $\mathrm{AgVO}_{3}, \mathrm{Ag}_{4} \mathrm{~V}_{2} \mathrm{O}_{7}$ and $\mathrm{Ag}_{3} \mathrm{VO}_{4}$ compounds were prepared via reflux at $80{ }^{\circ} \mathrm{C}$ for $30 \mathrm{~h}$. Silica gel beads with 2-3 mm in diameter (Fuji Silisia Chem.Co., CARiACT Q-50) were immersed into the precursor solution followed by drying on stainless steel mesh at $120{ }^{\circ} \mathrm{C}$ and sintering in air at temperatures from $350{ }^{\circ} \mathrm{C}$ to $450{ }^{\circ} \mathrm{C}$ for $30 \mathrm{~h}$. Thus $\mathrm{AgVO}_{3}$, $\mathrm{Ag}_{4} \mathrm{~V}_{2} \mathrm{O}_{7}$ and $\mathrm{Ag}_{3} \mathrm{VO}_{4}$ coated silica gel beads were prepared.

\subsection{Measurement of photocatalytic property of silica gel beads coated by $\mathrm{Ag}_{2} \mathrm{O}-\mathrm{V}_{2} \mathrm{O}_{5}$}

Methylene blue decomposition and acetaldehyde decomposition experiments were conducted under irradiation of black light, fluorescent light and in dark at room temperature. For methylene blue decomposition experiment, approximately $5 \mathrm{~cm}^{3}$ of photocatalyst coated silica gel beads were put into $50 \mathrm{~cm}^{3}$ methylene blue solution with $10 \mathrm{mg} / \mathrm{dm}^{3}$ in concentration. The solution was exposed to black light (10W) irradiation, fluorescent light (10W) irradiation and dark condition for various times between $30 \mathrm{~min}$ and $2880 \mathrm{~min}$ $(48 \mathrm{~h})$. And concentration of methylene blue of the solution was measured by the absorptiometry. The methylene blue 
solution subjected to $48 \mathrm{~h}$ decomposition experiment was measured by inductive coupled plasma atomic emission spectroscopy (SII, SPQ9600) to study photodissolution of components from the photocatalyst coated silica gel beads. For the acetaldehyde decomposition experiment, approximately $5 \mathrm{~cm}^{3}$ of photocatalyst coated silica gel beads were put in pyrex glass container with $1000 \mathrm{~cm}^{3}$ in volume. The container was then decompressed. And acetaldehyde was injected into the container with microsyringe so that concentration of acetaldehyde became $30 \mathrm{ppm}$. And air was introduced into the container so as to be atmospheric pressure. The container included photocatalyst and acetaldehyde was exposed to black light (10W), fluorescent light (10W) and dark condition for various times between $30 \mathrm{~min}$ and $2880 \mathrm{~min}(48 \mathrm{~h})$. After the experiment, concentration of acetaldehyde in the container was measured by gas chromatography (SHIMADZU, GC-14B).
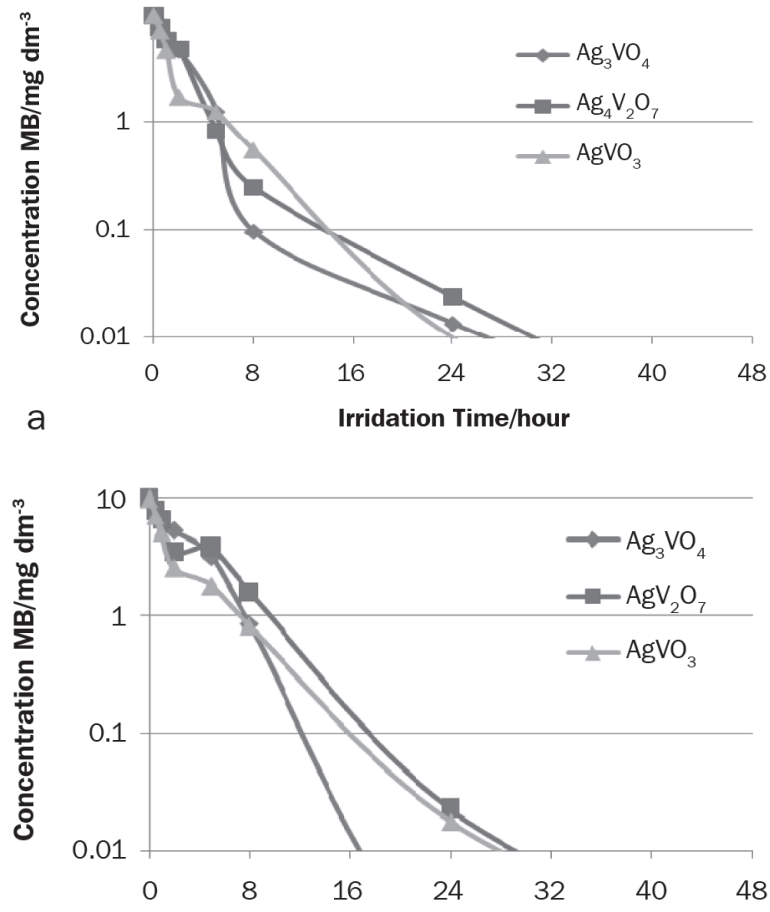

$\mathrm{b}$

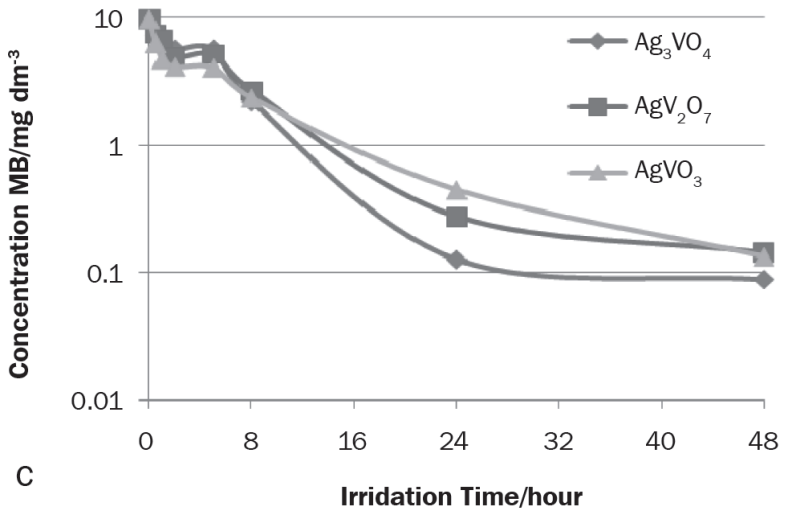

Fig. 2. Decomposition of methylene blue on $\mathrm{Ag}_{2} \mathrm{O}-\mathrm{V}_{2} \mathrm{O}_{5}$-coated silica gel beads in (a) ultraviolet light, (b) fluorescent light and (c) in darkness

2. ábra Metilénkék lebomlási jellemzői $\mathrm{Ag}_{2} \mathrm{O}_{-} \mathrm{V}_{2} \mathrm{O}_{5}$ vegyületekkel bevont szilikagél gyöngyökön (a) ultraibolya, (b) fluoreszcens fénnyel való besugárzás hatására, illetve (c) sötétben
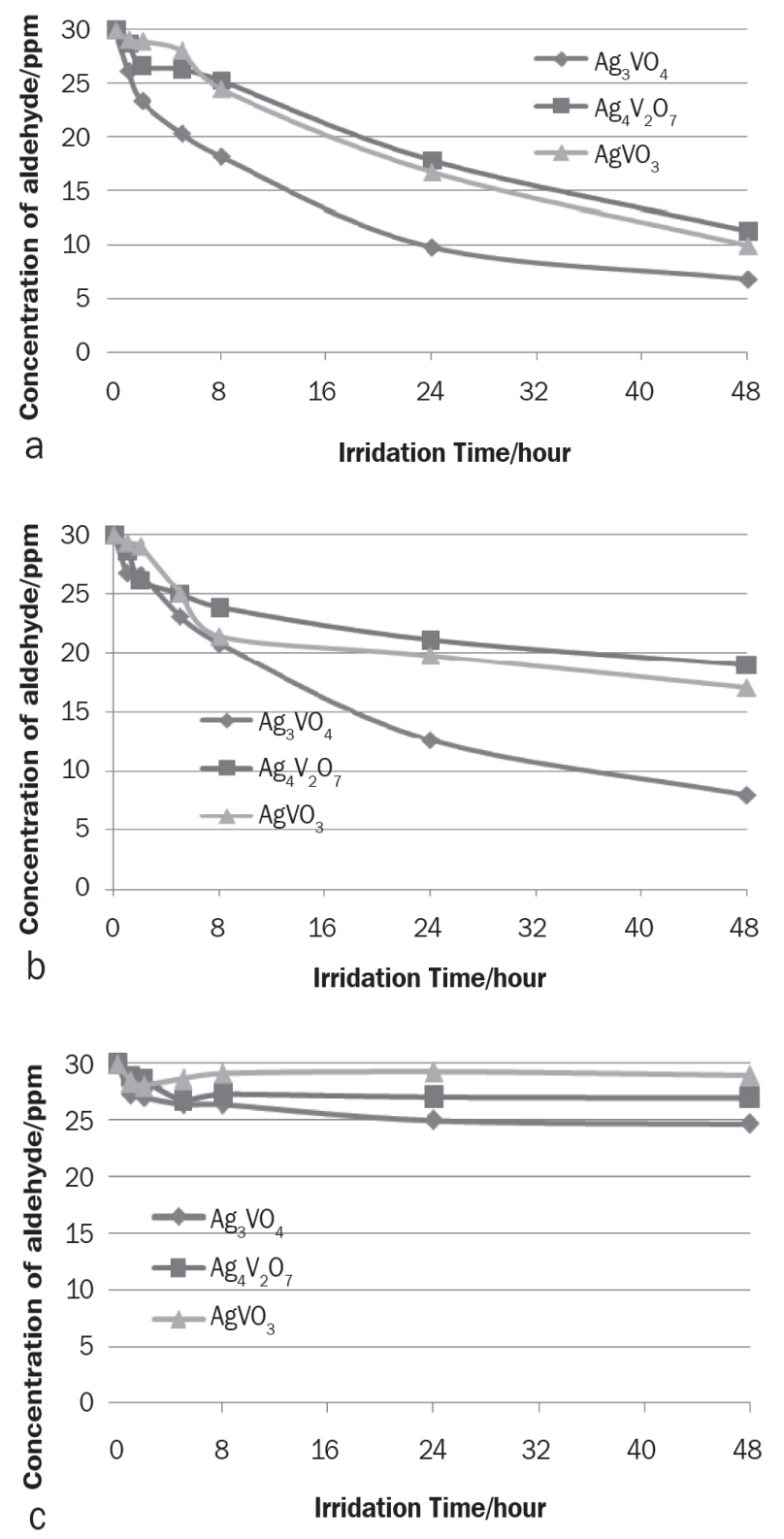

Fig. 3. Decomposition of acetaldehyde on $\mathrm{Ag}_{2} \mathrm{O}-\mathrm{V}_{2} \mathrm{O}_{5}$ powder mixture in (a) ultraviolet light, (b) fluorescent light and (c) in darkness

3. ábra Acetaldehid lebomlási jellemzői $\mathrm{Ag}_{2} \mathrm{O}-\mathrm{V}_{2} \mathrm{O}_{5}$ porvegyületeken (a) ultraibolya, (b) fluoreszcens fénnyel való besugárzás hatására, illetve (c) sötétben

\subsection{Platinum loaded $\mathrm{Ag}_{2} \mathrm{O}-\mathrm{V}_{2} \mathrm{O}_{5}$ compounds coated to silica gel beads}

Platinum cocatalyst loading onto $\mathrm{Ag}_{2} \mathrm{O}-\mathrm{V}_{2} \mathrm{O}_{5}$ compounds coated to silica gel beads was carried out to avoid recombination of excited electrons and electron holes. Hydrogen hexachloroplatinate (IV) hexahydrate (Kanto Chemical: 98.5\%) was added into the precursor solution mentioned Clause 2-1 so that concentration of $\mathrm{Pt}$ for photocatalyst became 1 mass $\%$. The solution was refluxed at $80{ }^{\circ} \mathrm{C}$ for $30 \mathrm{~h}$. Silica gel beads (Fuji Silisia Chem.Co., CARiACT Q-50) were immersed into the solution followed by drying on stainless steel mesh at $120^{\circ} \mathrm{C}$ and prepared in air at $450{ }^{\circ} \mathrm{C}$ for $30 \mathrm{~h}$. The samples were subjected to measurements of photocatalytic performance as mentioned Clause 2-2. 

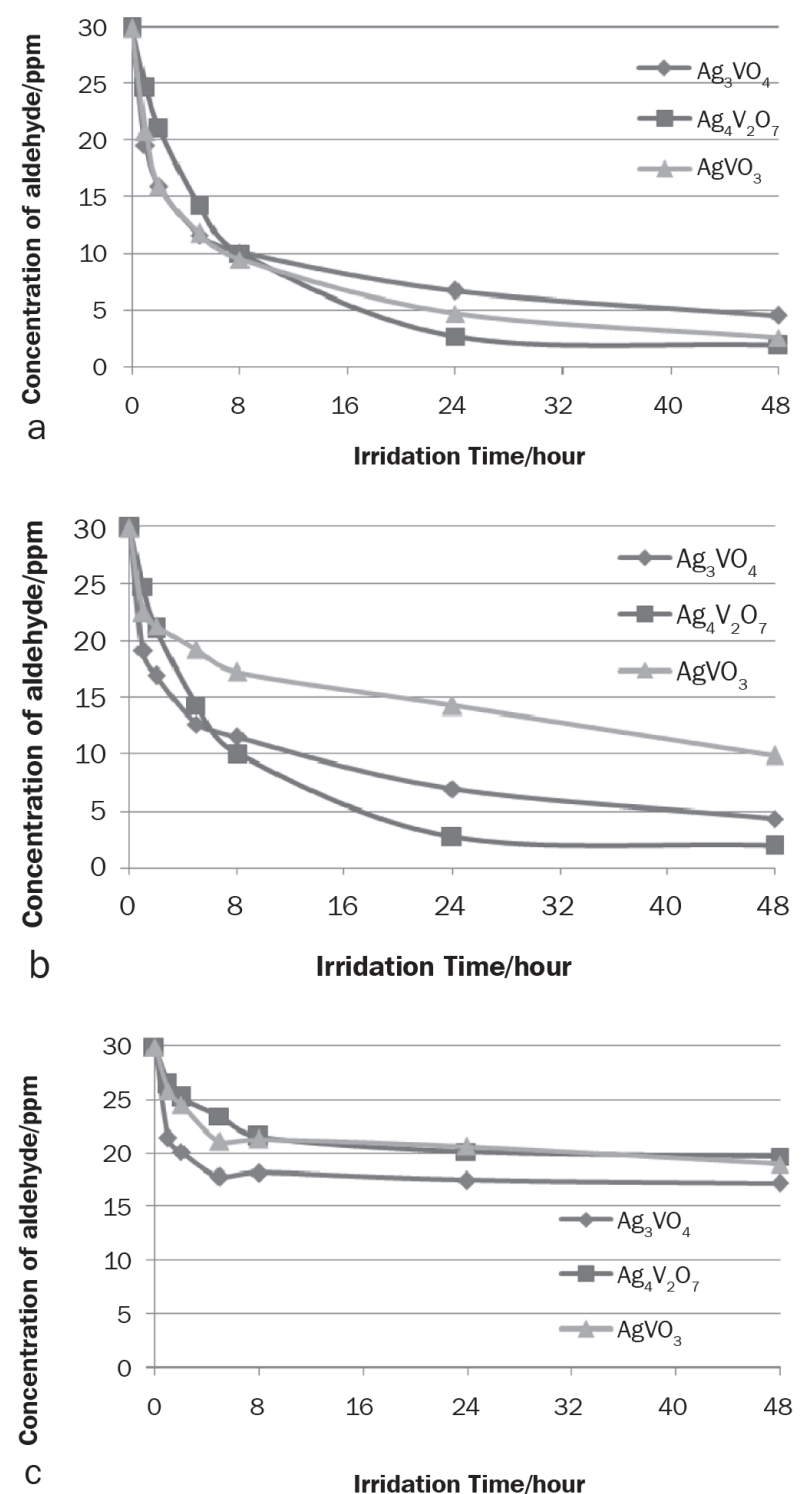

Fig. 4. Decomposition of acetaldehyde on $\mathrm{Ag}_{2} \mathrm{O}-\mathrm{V}_{2} \mathrm{O}_{5}$-coated silica gel beads in (a) ultraviolet light, (b) fluorescent light and (c) in darkness

4. ábra Acetaldehid lebomlási jellemzői $\mathrm{Ag}_{2} \mathrm{O}_{-} \mathrm{V}_{2} \mathrm{O}_{5}$ vegyületekkel bevont szilikagél gyöngyökön (a) ultraibolya, (b) fluoreszcens fénnyel való besugárzás hatására, illetve (c) sötétben

\section{Results and discussion}

Fig. 1. showed typical SEM photograph of the compounds coated silica gel beads. Thin films with approximately $400 \mathrm{~nm}$ in thickness were coated on silica gel beads. $\mathrm{AgVO}_{3}, \mathrm{Ag}_{4} \mathrm{~V}_{2} \mathrm{O}_{7}$ and $\mathrm{Ag}_{3} \mathrm{VO}_{4}$ coated silica gel beads prepared at temperatures from $350{ }^{\circ} \mathrm{C}$ to $450{ }^{\circ} \mathrm{C}$ were subjected to the methylene blue decomposition experiment. No exfoliation of the thin films from silica gel beads was observed during methylene blue decomposition experiment. Methylene blue decomposition characteristics of the compounds coated silica beads which showed the best performance for each compounds were illustrated in Fig. 2. Characteristics of mechylene blue decomposition via powder $\mathrm{AgVO}_{3}, \mathrm{Ag}_{4} \mathrm{~V}_{2} \mathrm{O}_{7}$ and $\mathrm{Ag}_{3} \mathrm{VO}_{4}$ were reported in the previous paper [7]. Concentration of methylene blue decreased remarkably for the solution with $\mathrm{AgVO}_{3}, \mathrm{Ag}_{4} \mathrm{~V}_{2} \mathrm{O}_{7}$ and $\mathrm{Ag}_{3} \mathrm{VO}_{4}$ coated silica gel beads as shown in Fig. $2 \mathrm{a}$. and $\mathrm{b}$.
The decrease results from adsorption of methylene blue to silica gel beads and followed by decomposition via photocatalysis. The decrease in concentration of methylene blue as shown in Fig. 2c. might be resulted from adsorption to silica gel beads. Because the powder compounds, such as $\mathrm{AgVO}_{3}$, $\mathrm{Ag}_{4} \mathrm{~V}_{2} \mathrm{O}_{7}$ and $\mathrm{Ag}_{3} \mathrm{VO}_{4}$ did not show photocatalytic activity in dark [7]. ICP atomic emission spectroscopy measurements revealed that approximately $3 \times 10^{-5} \mathrm{~mol} / \mathrm{dm}^{3}$ of $\mathrm{AgVO}_{3}, 6 \times 10^{-}$ ${ }^{6} \mathrm{~mol} / \mathrm{dm}^{3}$ of $\mathrm{Ag}_{4} \mathrm{~V}_{2} \mathrm{O}_{7}$ and $1 \times 10^{-5} \mathrm{~mol} / \mathrm{dm}^{3}$ of $\mathrm{Ag}_{3} \mathrm{VO}_{4}$ were dissolved into the solution from the compounds coated to silica gel beads after $48 \mathrm{~h}$ photodissolution experiment. The values are the same order as that of powder samples [7]. Fig. 3. showed acetaldehyde decomposition characteristics via $\mathrm{Ag}_{2} \mathrm{O}-\mathrm{V}_{2} \mathrm{O}_{5}$ powder compounds under irradiation of black light, fluorescent light and in dark. Acetaldehyde was oxidized to acetic acid and followed by decomposed to carbon dioxide and water by photocatalyst. The same decomposition characteristics were observed for the experiments under black light and fluorescent light irradiations. $\mathrm{Ag}_{3} \mathrm{VO}_{4}$ powder showed superior decomposition performance than $\mathrm{AgVO}_{3}$ and $\mathrm{Ag}_{4} \mathrm{~V}_{2} \mathrm{O}_{7}$. The decrease in concentration of acetaldehyde shown in Fig. 3c. might be result from adsorption to powder samples. Fig. 4. showed acetaldehyde decomposition characteristics via photocatalysts coated silica gel beads. Performance for decomposition of acetaldehyde was improved remarkably compared to that of powder samples. Acetaldehyde adsorption to silica gel beads might play an important role for the decomposition, because the decomposition reaction takes quite long time. Consequently, it is necessary for the decomposition that photocatalyst, acetaldehyde and light exist simultaneously for a long time. Comparing with Fig. 4c. to Fig. 3c., photocatalysts coated silica gel beads absorbed much more acetaldehyde than powder photocatalysts. And large quantity of acetaldehyde can coexist with photocatalyst on silica gel beads. Fig. 5. showed that photocatalytic performances under fluorescent light irradiation for $\mathrm{Ag}_{3} \mathrm{VO}_{4}$ and Pt co-catalyst loaded $\mathrm{Ag}_{3} \mathrm{VO}_{4}$ coated to silica gel beads prepared at $450{ }^{\circ} \mathrm{C}$. Fig. $5 \mathrm{a}$. and b. showed methylene blue and acetaldehyde decomposition characteristics, respectively. Photocatalytic performance of $\mathrm{Pt}$ loaded $\mathrm{Ag}_{3} \mathrm{VO}_{4}$ coated silica gel beads was remarkably improved. A similar tendency was observed for the other photocatalysts. It was elucidated that $\mathrm{Pt}$ co-catalyst loading to $\mathrm{Ag}_{2} \mathrm{O}-\mathrm{V}_{2} \mathrm{O}_{5}$ compounds coated to silica gel beads was effective for an enhancement of photocatalytic performance.

\section{Conclusions}

Remarkable improvement of photocatalytic activity was observed for the compounds coated silica gel beads compared to powder samples. No exfoliation of the thin films from silica gel beads was observed during methylene blue decomposition experiment. Approximately $3 \times 10^{-5} \mathrm{~mol} / \mathrm{dm}^{3}$ of $\mathrm{AgVO}_{3}$, $6 \times 10^{-6} \mathrm{~mol} / \mathrm{dm}^{3}$ of $\mathrm{Ag}_{4} \mathrm{~V}_{2} \mathrm{O}_{7}$ and $1 \times 10^{-5} \mathrm{~mol} / \mathrm{dm}^{3}$ of $\mathrm{Ag}_{3} \mathrm{VO}_{4}$ were dissolved into the solution from the compounds coated to silica gel after $48 \mathrm{~h}$ photodissolution experiment. Pt co-catalyst loading to $\mathrm{Ag}_{2} \mathrm{O}-\mathrm{V}_{2} \mathrm{O}_{5}$ compounds coated to silica gel beads was effective for an enhancement of photocatalytic performance. 


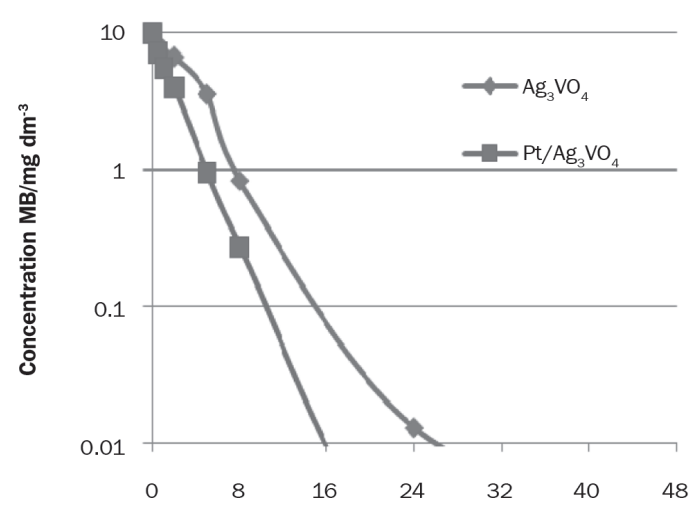

a

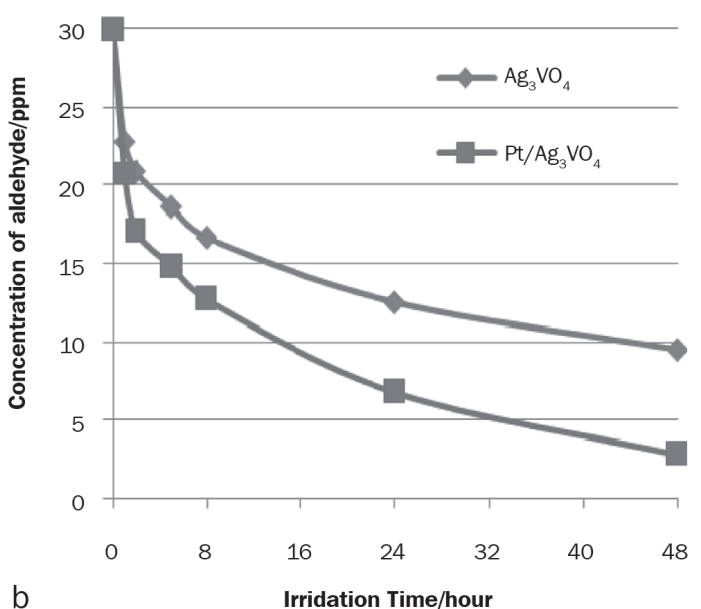

Fig. 5. Photocatalytic performance of silica gel beads coated with $\mathrm{Ag}_{3} \mathrm{VO}_{4}$ and Pt loaded $\mathrm{Ag}_{3} \mathrm{VO}_{4}$, respectively in fluorescent light (a) decomposition of methylene blue and $(b)$ decomposition of acetaldehyde

5. ábra $\mathrm{Ag}_{3} \mathrm{VO}_{4}$ és platina kokatalizátort tartalmazó $\mathrm{Ag} \mathrm{g}_{3} \mathrm{VO}$ vegyületekkel bevont szilikagél gyöngyök fotokatalitikus teljesitménye fluoreszcens fénybesugárzás hatása alatt. (a) metilénkék lebomlása, (b) acetaldehid lebomlása

\section{References}

[1] A. Fujisima - K. Honda: Electrochemical photolysis of water at a semiconductor electrode, Nature, 238, 37-38, 1971.
[1] Z. Zou - J. Ye - H. Arakawa: Structural properties of InNbO and InTaO Correlation with photocatalytic and photophysical properties, Chem. Phys. Letter, 332, (2000), pp. 271-277.

[2] Z. Zou - J. Ye - K. Sayama - H. Arakawa: Direct splitting of water under visible light irradiation with an oxide semiconductor photocatalyst, Nature, 414, (2001), pp.625-627.

[3] M. Hara - G. Hitoki - T. Takata - J. N. Kondo - H. Kobayashi - K. Domen: TaON and Ta3N5 as new visible light driven photocatalysts, Catal. Today., 78 (1-4), (2003), pp.555-560.

[4] J. Ye - Z. Zou - M. Oshikiri - A. Matsushita - M. Shinoda - M. Imai - T. Shishido: A novel hydrogen-evolving photocatalyst $\mathrm{InVO}_{4}$ active under visible light irradiation, Chem. Phys. Lett., 356, (2002 ), pp.221-226.

[5] R. Konta - H. Kato - H. Kobayashi - A. Kudo: Photophysical properties and photocatalytic activities under visible light irradiation of silver vanadates, Physical Chem. Chemical Phys. 5(14), (2003), pp.3061-3065.

[6] A. Kurihara - Y. Takagi - K. Kuribayashi: Synthesis of visible light responsive photocatalyst and its properties, Bull. Teikyo Univ. Sci. and Tech. 3, (2007), pp.37-43.

[7] K. Kuribayashi - E. Nozawa - Y. Iyama - H. Hirai - S. Namba T. Kugita: Synthesis and Photocatalytic Property of the Ag-Rich Compounds in the System $\mathrm{Ag}_{2} \mathrm{O}-\mathrm{V}_{2} \mathrm{O}_{5}$, Proceedings of the $2^{\text {nd }}$ International Conference on Ceramics, Verona, ITALY, (2008), THEME 5-P15.

\section{$\mathrm{Ag}_{2} \mathrm{O}-\mathrm{V}_{2} \mathrm{O}_{5}$ vegyületekkel bevont szilikagél gyöngyök fotokatalitikus tulajdonságai}

Szilikagél gyöngyöket $\mathrm{AgVO}_{3}, \mathrm{Ag}_{4} \mathrm{~V}_{2} \mathrm{O}_{7}$ és $\mathrm{Ag}_{3} \mathrm{VO}_{4}$ összetételú vegyületekkel vontunk be, majd mértük fotokatalitikus tulajdonságaikat. A mérések során fluoreszcens (fénycsővilágítás) és ultraibolya fénynek kitett, illetve sötétben tartott gyöngyökön a metilénkék és acetaldehid indikátorok lebomlását vizsgáltuk. A fotokatalitikus rétegek vastagsága a gyöngyökön kb. $400 \mathrm{~nm}$ volt. A kísérleti besugárzás során nem tapasztaltuk a fényérzékeny rétegek lehámlását a szilikagél gyöngyökrốl. A pormintákhoz képest a szilikagél gyöngyök bevonatainak fotokatalitikus aktivitása számottevően nagyobb volt. Különösen az $\mathrm{Ag}_{3} \mathrm{VO}_{4}$ bevonatú szilikagél gyöngyöknél volt jelentôs a metilénkék lebomlása (a 16 órán át tartó fluoreszcens besugárzás alatt $10 \mathrm{mg} / \mathrm{dm}^{3}$ értékrôl kevesebb, mint $0,01 \mathrm{mg} / \mathrm{dm}^{3}$ értékre). Az is nyilvánvalóvá vált, hogy Pt kokatalizátor hozzáadása a szilikagél gyöngyök bevonatához javította annak fotokatalitikus teljesítményét.

Kulcsszavak: fotokatalizátor, $\mathrm{Ag}_{2} \mathrm{O}-\mathrm{V}_{2} \mathrm{O}_{5}$ vegyületek, metilénkék bomlása, acetaldehid bomlása 